\title{
Novel 4-substituted phenyl-2,2'-bichalcophenes and aza-analogs as antibacterial agents: a structural activity relationship
}

This article was published in the following Dove Press journal:

Drug Design, Development and Therapy

21 March 2013

Number of times this article has been viewed

\author{
Warda A Hussin' \\ Mohamed A Ismail 2,3 \\ Wael M El-Sayed ${ }^{2,4}$ \\ 'Al-Azhr University, Faculty of \\ Science, Department of Botany \\ and Microbiology, Cairo; ${ }^{2}$ King \\ Faisal University, Faculty of Science, \\ Departments of Biological Sciences \\ and Chemistry, Al-Hufof, Ahsaa, KSA; \\ ${ }^{3}$ Mansoura University, Faculty of \\ Science, Department of Chemistry, \\ Mansoura; ${ }^{4}$ University of Ain Shams, \\ Faculty of Science, Department of \\ Zoology, Abbassia, Cairo, Egypt
}

\begin{abstract}
Antibiotic resistance is a major health problem; therefore, new antibacterial agents will need to be continuously developed. A series of novel bichalcophenes has been tested and found to have antimicrobial activity against selected bacteria. Due to the promising antimicrobial effects of these 4-substituted phenyl bichalcophene derivatives, the study reported here was launched to examine the interaction between novel bichalcophenes and tetracycline. The minimum inhibitory concentration values for all bichalcophenes were between 8 and $64 \mu \mathrm{M}$. Many of the bichalcophenes had synergistic activity that increased the inhibitory effect of tetracycline against bacterial growth, as indicated by the fractional inhibitory concentration index. The post-antibiotic effects of the novel bichalcophenes were determined. Many bichalcophenes were able to elongate the period required for bacteria to recover and grow after a brief exposure to tetracycline. Escherichia coli did not develop resistance to many bichalcophenes over a period of 7 days. A structural activity relationship could be characterized, as monocationic derivatives were more active than the corresponding mononitriles. The presence of a pyridyl group and/ or furan ring reduced the activity, while the presence of a phenyl or thiophene ring enhanced the antibacterial activity. Our results suggest that bichalcophenes could be useful to elevate the shelf life of many antibiotics.
\end{abstract}

Keywords: synergic interaction, fractional inhibitory concentration, post-antibiotic effect, resistant variants

\section{Introduction}

Since the discovery of penicillin, many antibiotics have been developed to control bacterial infections. ${ }^{1}$ The use of antibacterial agents along with improved sanitary conditions suggested that industrialized nations had won the war against pathogenic microbes. However, over the past few years, bacterial resistance to antibiotics has developed and resistance to multiple antimicrobial agents has become a major health problem. ${ }^{2}$ Many factors affect the rate of development of resistance, including excessive use and misuse of antibiotics. ${ }^{3}$ Due to the development of antibiotic resistance in virtually all clinically important pathogens, new antibacterial agents will need to be continuously developed.

Aromatic dicationic compounds, such as pentamidine, furamidine, and their analogs, have been reported to have broad-spectrum antimicrobial effects against fungi and bacteria. ${ }^{4,5}$ The antimicrobial activity of pentamidine has been recognized for over 50 years and pentamidine remains the only aromatic diamidine that has been significantly used in the drug industry. ${ }^{6}$ However, due to the poor oral bioavailability and unfavorable side-effects of many diamidines, numerous new compounds have
Correspondence: Wael M El-Sayed Department of Zoology, Faculty of Science, University of Ain Shams, Abbassia II566, Cairo, Egypt

Tel +2022482 I 633

Fax +20226842123

Email waelelhalawany@hotmail.com 
been synthesized aimed at improving these deficiencies. ${ }^{7}$ Thiophene-, furan-, and nitrile-containing compounds have been synthesized and shown to exhibit a broad-spectrum antimicrobial activity. ${ }^{8-12}$ Recently, a series of type I dicationic bichalcophenes (Figure 1) and aza-analogs of furamidine have been reported to be antiprotozoal agents. ${ }^{11,13}$

A series of type II 4-substituted phenyl bichalcophenes (Figure 1) have been synthesized and tested for their antimicrobial activity against the growth of several bacteria. ${ }^{14}$ Due to the promising antimicrobial effects of these 4-substituted phenyl bichalcophene derivatives, the study reported here was launched to examine the interaction between type II novel bichalcophenes and tetracycline by calculating the fractional inhibitory concentration (FIC) of each combination against selected bacteria. Moreover, the effect of the bichalcophenes on the suppression of bacterial growth that persists after a brief exposure of Escherichia coli to tetracycline (known as "post-antibiotic effect" [PAE]) was determined. The increased PAE in the presence of bichalcophenes could offer an alternative way for extension of the useful lifespan

A<smiles>[X]c1c[Z]c(-c2ccc(C(=N)N)[Y]2[H])cc1</smiles><smiles></smiles>

I,II : Z = CH,N $X, Y=O, S$

B<smiles>N#Cc1ccc(-c2ccc(-c3ccco3)o2)cc1</smiles><smiles>N=C(N)c1ccc(-c2ccc(-c3ccco3)o2)cc1</smiles><smiles>N#Cc1ccc(-c2ccc(-c3ccco3)o2)nc1</smiles><smiles>N=C(N)c1ccc(-c2ccc(-c3ccco3)o2)nc1</smiles><smiles>N#Cc1ccc(-c2ccc(-c3cccs3)o2)cc1</smiles><smiles>N=C(N)c1ccc(-c2ccc(-c3cccs3)o2)cc1</smiles><smiles>N#Cc1ccc(-c2ccc(-c3cccs3)o2)nc1</smiles><smiles>N=C(N)c1ccc(-c2ccc(-c3cccs3)o2)nc1</smiles><smiles>N#Cc1ccc(-c2ccc(-c3cccs3)s2)cc1</smiles><smiles>N=C(N)c1ccc(-c2ccc(-c3cccs3)s2)cc1</smiles>

Figure I (A) Structures of some biologically important cationic bichalcophene compounds. (B) 4-substituted phenyl-2,2'-bichalcophenes and aza-analogs as potent antibacterial agents. 
of antibiotics. ${ }^{15}$ The rationale behind the selection of tetracycline was to test the potency of novel bichalcophenes to enhance the efficacy of an antibiotic that has lost efficiency and against which many bacteria have acquired resistance. In addition, to investigate the stability of the tested compounds as antimicrobial agents, the development of spontaneous resistance to bichalcophenes was investigated.

\section{Materials and methods Chemicals}

All reagents were purchased from Sigma-Aldrich (St Louis, MO, USA) except where indicated in the specified methods. Ten bichalcophene derivatives were used throughout the study (Figure 1). Bichalcophenes were sterilized by filtration through a $0.2 \mu \mathrm{m}$ filter (Nalgene, Rochester, NY, USA).

\section{Bacterial strains}

The tested bacterial strains were purchased from the American Type Culture Collection (ATCC; Manassas, VA, USA). The antibacterial assays were performed against standard strains of Gram-positive (Staphylococcus aureus ATCC 25923 and Bacillus megaterium ATCC 14591) and Gramnegative (E. coli ATCC 25922, Pseudomonas aeruginosa ATCC 27853, and Klebsiella pneumoniae ATCC 700603) bacteria. All procedures were approved by the Committee of Scientific Research Ethics of King Faisal University.

\section{Minimum inhibitory concentration (MIC) of the novel bichalcophene derivatives}

The MIC of the novel bichalcophenes was determined according to the Clinical and Laboratory Standards Institute guidelines. ${ }^{16} \mathrm{An}$ inoculum density of $5 \times 10^{5}$ colony forming units $(\mathrm{CFU}) / \mathrm{mL}$ of each organism was dispensed into the wells of a 96-well microtiter plate. The bichalcophenes were serially $(1-128 \mu \mathrm{M})$ diluted in the wells followed by the addition of bacteria. The plates were incubated at $37^{\circ} \mathrm{C}$ for 18 hours and the absorbance was recorded at $600 \mathrm{~nm}$. The MIC value was recorded as the lowest concentration at which no growth was observed. All MIC values were determined on three independent experiments.

\section{Synergic interaction between the tested bichalcophenes and tetracycline}

A combination of each bichalcophene at 0.25 or $0.5 \times \mathrm{MIC}$ and tetracycline $(0.25-128 \mu \mathrm{g} / \mathrm{mL})$ was prepared and inoculated with $5 \times 10^{5} \mathrm{CFU} / \mathrm{mL}$ of each strain. The plates were incubated at $37^{\circ} \mathrm{C}$ for 18 hours, and the lowest antibiotic concentration in combination with bichalcophene that prevented the development of growth was regarded as the MIC*. The FIC was calculated as follows: ${ }^{17} \mathrm{FIC}$ of tetracycline $=\mathrm{MIC} *(\mathrm{com}-$ bination of tetracycline + bichalcophene)/MIC of tetracycline alone. An FIC $\leq 0.5$ indicated synergy, an FIC $>0.5-4.0$ indicated indifference, and an FIC $>4$ indicated antagonism.

\section{PAE}

The E. coli inocula equivalent to $10^{6} \mathrm{CFU} / \mathrm{mL}$ were incubated at $37^{\circ} \mathrm{C}$ for 30 minutes with tetracycline $(1 \times \mathrm{MIC})$, each bichalcophene $(0.25 \times \mathrm{MIC})$, or a combination of each bichalcophene and tetracycline $(0.25 \times \mathrm{MIC}+1 \times \mathrm{MIC}$, respectively). After 30 minutes, bacteria were diluted 1000fold with Müeller-Hinton broth (MHB) to eradicate the antibiotic and/or bichalcophene. A $100 \mu \mathrm{L}$ sample of each treatment was obtained at time zero and every hour thereafter until turbidity developed, and spread onto nutrient agar for total viable cell count after incubation at $37^{\circ} \mathrm{C}$ for 24 hours. The PAE was calculated as described by Craig and Gudmundsson: ${ }^{18}$ $\mathrm{PAE}=\mathrm{T}-\mathrm{C}$, in which $\mathrm{T}$ is the time required for the viable cell count of the exposed bacteria to increase by a factor of $\log _{10}$ from the initial time immediately after washing, and $\mathrm{C}$ is the corresponding time for cells unexposed to either antibiotic or bichalcophenes. Each assay was carried out in triplicate. To avoid overgrowth of the control culture, a 100-fold dilution was prepared using MHB at every time interval.

\section{Detection of bichalcophenes- resistant variants}

To evaluate the development of spontaneous resistance in E. coli against bichalcophenes or tetracycline, growth assays were performed using $E$. coli in the presence or absence of each bichalcophene or tetracycline. Twenty milliliters of cells in the logarithmic growth phase were centrifuged, and the cells were resuspended in $2 \mathrm{~mL}$ of MHB. The inoculum density was adjusted to $10^{8} \mathrm{CFU} / \mathrm{mL}$. Different concentrations of each bichalcophene $(3,2,1 \times$ MIC) were added. All plates were incubated at $37^{\circ} \mathrm{C}$ and the absorbance was recorded at $600 \mathrm{~nm}$ daily for 7 days. ${ }^{19}$

\section{Statistical analysis}

Statistical analyses were performed using analysis of variance followed by Fisher's protected least significant difference multiple-range test. Differences were considered significant at $P$ values $<0.05$.

\section{Results}

The bichalcophenes had broad-spectrum activities against the tested bacteria. Compound 5B was the most effective 
against all bacteria, with an MIC value at $8 \mu \mathrm{M}(2.7 \mu \mathrm{g} / \mathrm{mL})$. Compounds $1 \mathrm{~A}$ and $2 \mathrm{~A}$ were alike in inhibiting the growth of bacteria, with an MIC value at $32 \mu \mathrm{M}$. Gram-positive bacteria were more sensitive to Compounds 3A, 4A, and 5A (MIC $32 \mu \mathrm{M}$ ) than Gram-negative strains (MIC $64 \mu \mathrm{M}$ ). Similarly, Compounds $3 \mathrm{~B}$ and $4 \mathrm{~B}$ were most effective in inhibiting the growth of Gram-positive bacteria (MIC $16 \mu \mathrm{M}$ ), while the MIC value against Gram-negative bacteria was $32 \mu \mathrm{M}$. Compounds $1 \mathrm{~B}$ and $2 \mathrm{~B}$ showed the same pattern, with MIC values at $16 \mu \mathrm{M}$ against $S$. aureus, B. megaterium, and E. coli and $32 \mu \mathrm{M}$ against $P$. aeruginosa and $K$. pneumoniae (Table 1).

The interaction of each bichalcophene at a concentration of 0.25 or $0.5 \times \mathrm{MIC}$ with various concentrations of tetracycline $(0.25-128 \mu \mathrm{g} / \mathrm{mL})$ was examined (Table 2$)$. The reported MIC values for tetracycline were $4 \mu \mathrm{g} / \mathrm{mL}$ against $B$. megaterium, $8 \mu \mathrm{g} / \mathrm{mL}$ against $S$. aureus, E. coli, and $P$. aeruginosa, and $16 \mu \mathrm{g} / \mathrm{mL}$ against $K$. pneumoniae (Table 1). With the exception of Compound 2A, all bichalcophenes at $0.25 \times \mathrm{MIC}$ had a synergic effect on the activity of tetracycline against $K$. pneumoniae and antagonized the activity of tetracycline against the growth of all other tested bacteria ( $\mathrm{FIC}>4$ ). With the exception of Compounds $2 \mathrm{~A}$ and $3 \mathrm{~A}$ against $S$. aureus and $P$. aeruginosa and $4 \mathrm{~A}$ and $4 \mathrm{~B}$ against $P$. aeruginosa, all bichalcophenes at $0.5 \times \mathrm{MIC}$ acted synergistically with tetracycline against the growth of all bacterial strains under investigation (Table 2). Compounds $1 \mathrm{~A}, 1 \mathrm{~B}$, and $3 \mathrm{~B}$ at $0.25 \times \mathrm{MIC}$ were similar in potentiating the activity of tetracycline against all tested bacteria except S. aureus $(\mathrm{FIC}=2)$. Indifference (FIC $>0.5-4.0)$ was shown with Compound $5 \mathrm{~A}$ at the lowest concentration against $S$. aureus and B. megaterium, while it increased the activity of tetracycline against Gram-negative bacteria. Compounds 2B and $5 \mathrm{~B}$ at both concentrations investigated were the most effective in inhibiting the growth of all tested bacteria when used in combination with tetracycline, with both achieving additive effects, as indicated by the FIC values (0.063-0.500). The effect of Compound $3 \mathrm{~A}$ on the activity of tetracycline varied with the tested bacteria, with indifferent effects reported with $S$. aureus (at both concentrations) and E. coli (only at low concentration), and an antagonistic activity against the growth of $P$. aeruginosa at both concentrations and a synergic effect was shown against $B$. megaterium and $K$. pneumoniae. Synergic effect was reported with Compound $4 \mathrm{~B}$ against the growth of B. megaterium, E. coli, and K. pneumoniae, and an antagonistic effect against $P$. aeruginosa. Compound 4A did not affect the tetracycline activity against $B$. megaterium, $E$. coli, or $S$. aureus only at $0.25 \times \mathrm{MIC}$ and antagonized the tetracycline activity when used against $P$. aeruginos $a$ at both 0.25 and $0.5 \times$ MIC (Table 2).

The estimated PAE for tetracycline was 2 hours. Using bichalcophenes $1 \mathrm{~A}-4 \mathrm{~A}$ and $4 \mathrm{~B}$ resulted in PAEs of 2 hours. The recorded PAE for $5 \mathrm{~A}, 1 \mathrm{~B}$, and $2 \mathrm{~B}$ was 3 hours. Compounds $3 \mathrm{~B}$ and $5 \mathrm{~B}$ were more effective in suppressing $E$. coli growth for 5 and 6 hours, respectively. The combination of Compound $1 \mathrm{~A}$ or $5 \mathrm{~A}$ with tetracycline resulted in a PAE of 3 hours. The combination of $3 \mathrm{~A}, 2 \mathrm{~B}$, or $4 \mathrm{~B}$ with tetracycline had similar effects, elevating the PAE value to 4 hours. Compounds 1B, 3B, and 5B seemed the most effective at extending the suppression time of bacterial growth, with PAEs of 6, 7, and 7 hours, respectively. However, Compounds $2 \mathrm{~A}$ and $4 \mathrm{~A}$ had no effect on PAE value as compared to unexposed control cells (Figure 2).

On investigation of the development of resistant variants, a high frequency of resistance development was detected with tetracycline after 2 days of incubation at $1 \times \operatorname{MIC}(8 \mu \mathrm{g} / \mathrm{mL})$.

Table I Minimum inhibitory concentration (MIC) of the bichalcophene derivatives against different bacterial strains

\begin{tabular}{|c|c|c|c|c|c|}
\hline \multirow{2}{*}{$\begin{array}{l}\text { Tested compound } \\
\mu \mathrm{M}(\mu \mathrm{g} / \mathrm{mL})\end{array}$} & \multicolumn{5}{|l|}{$\mathbf{M I C}^{a}$} \\
\hline & $\begin{array}{l}\text { Staphylococcus } \\
\text { aureus }\end{array}$ & $\begin{array}{l}\text { Bacillus } \\
\text { megaterium }\end{array}$ & $\begin{array}{l}\text { Escherichia } \\
\text { coli }\end{array}$ & $\begin{array}{l}\text { Pseudomonas } \\
\text { aeruginosa }\end{array}$ & $\begin{array}{l}\text { Klebsiella } \\
\text { pneumoniae }\end{array}$ \\
\hline Tetracycline $(\mathrm{mg} / \mathrm{mL})$ & 8 & 4 & 8 & 8 & 16 \\
\hline IA & $32(7.5)$ & $32(7.5)$ & $32(7.5)$ & $32(7.5)$ & $32(7.5)$ \\
\hline IB & $16(4.6)$ & $16(4.6)$ & $16(4.6)$ & $32(9.2)$ & $32(9.2)$ \\
\hline $2 \mathrm{~A}$ & $32(7.6)$ & $32(7.6)$ & $32(7.6)$ & $32(7.6)$ & $32(7.6)$ \\
\hline $2 B$ & $16(5.4)$ & $16(5.4)$ & $16(5.4)$ & $32(10.7)$ & $32(10.7)$ \\
\hline $3 \mathrm{~A}$ & $32(8.0)$ & $32(8.0)$ & $64(16.0)$ & $64(16.0)$ & $64(16.0)$ \\
\hline $3 B$ & $16(4.9)$ & $16(4.9)$ & $32(9.9)$ & $32(9.9)$ & $32(9.9)$ \\
\hline $4 \mathrm{~A}$ & $32(8.1)$ & $32(8.1)$ & $64(16.1)$ & $64(16.1)$ & $64(16.1)$ \\
\hline $4 B$ & $16(5.5)$ & $16(5.5)$ & $32(11.0)$ & $32(11.0)$ & $32(11.0)$ \\
\hline $5 \mathrm{~A}$ & $32(8.6)$ & $32(8.6)$ & $64(17.1)$ & $64(17.1)$ & $64(17.1)$ \\
\hline $5 B$ & $8(2.7)$ & $8(2.7)$ & $8(2.7)$ & $8(2.7)$ & $8(2.7)$ \\
\hline
\end{tabular}

Note: a Data are expressed as the means of three independent experiments. 


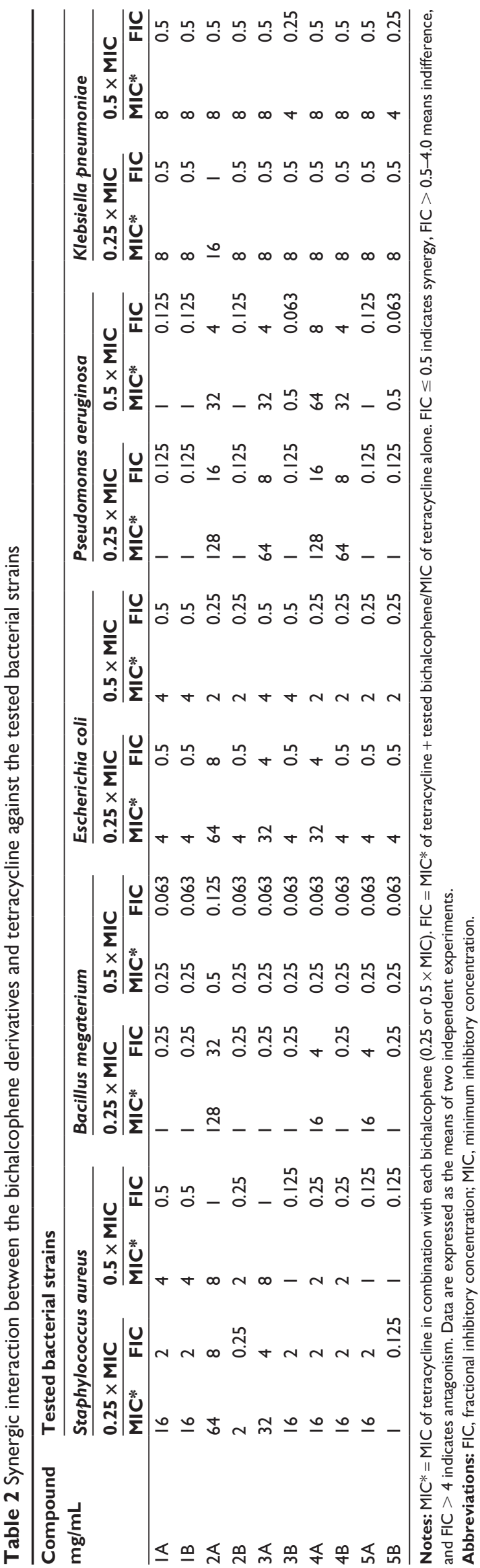

Using higher concentrations of tetracycline $(2$ and $3 \times$ MIC) delayed the bacterial growth until day 5. Compounds $1 \mathrm{~B}$, $3 \mathrm{~B}$, and $5 \mathrm{~B}$ were effective at preventing the growth of bacteria even after 7 days of incubation at all concentrations examined. In contrast, the development of resistance against Compounds 2A and 2B was reported after day 2 (Figure 3). Compounds 3A, 4A, 5A, and 4B were only potent at preventing the bacterial growth at the highest concentration $(3 \times$ MIC $)$ investigated and cells failed to develop resistance after day 7 . However, at the lowest concentration $(1 \times \mathrm{MIC})$, the growth of bacterial cells was detected at day 2 . The development of resistance against Compounds 4A, 5A, and $4 \mathrm{~B}$ at $2 \times$ MIC occurred at days 5, 4, and 3, respectively. Exposing E. coli cells to Compound 3A delayed the emergence of resistance until day 6. Similarly, Compound $1 \mathrm{~A}$ was effective at preventing the growth of $E$. coli at the high concentrations used -2 and $3 \times$ MIC - until 5 and 6 days post-incubation, respectively (Figure 3 ).

\section{Discussion}

The emergence of antibiotic resistance in bacteria is a serious problem facing humanity. The rate at which this resistance develops exceeds the rate of antibiotic development and production. Many antibiotics are now ineffective and the efficacy of many others is declining. Therefore, there must be a continuous and extensive effort to develop novel antimicrobial agents or increase the efficacy of the antibiotics currently in use by reducing the development of resistance in bacteria. Thus, five phenyl bichalcophene derivatives and their corresponding aza-analogs were synthesized and found to have significant antimicrobial activity. ${ }^{14}$ These novel bichalcophenes were designed to achieve maximum antimicrobial activity, have low toxicity, and have better pharmacological properties than other biologically active amidines. These bichalcophenes contain furan and thiophene rings, which are known for their efficient biological activity, ${ }^{20,21}$ and through introducing either a monoamidine or cyano group, this activity could be enhanced. In addition, the ability of these novel compounds to act synergistically with tetracycline was also investigated, a property that can be used to enhance or revive many antibiotics that have lost their efficiency.

All monocationic bichalcophenes were more effective than their corresponding mononitrile derivatives. The MIC values of monocationic derivatives used in this study were between 8 and $32 \mu \mathrm{M}$, while those of mononitriles were between 32 and $64 \mu \mathrm{M}$ (Table 1). The reported antimicrobial activity of the bichalcophenes can be attributed to the 

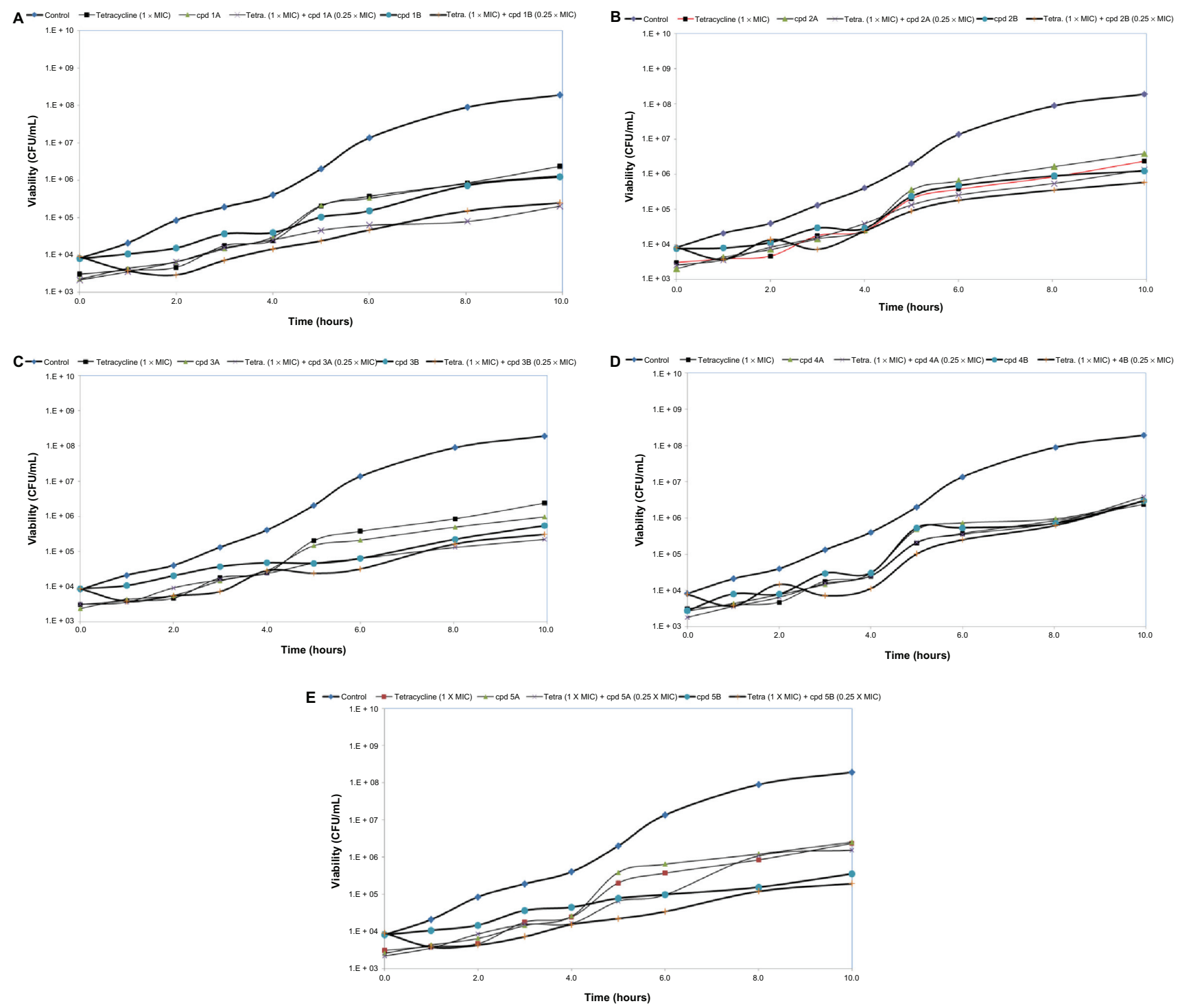

Figure 2 The post-antibiotic effect of bichalcophenes $(0.25 \times \mathrm{MIC})$, tetracycline $(\mathrm{I} \times \mathrm{MIC})$, or a combination of bichalcophenes and tetracycline on Escherichia coli American Type Culture Collection 25922. The control curve represents the growth of bacteria unexposed to either bichalcophenes or tetracycline. (A) Compounds IA and IB; (B) Compounds 2A and 2B; (C) Compounds 3A and 3B; (D) Compounds 4A and 4B; (E) Compounds 5A and 5B.

Notes: Data are expressed as the mean of three independent assays. Standard error of the mean has been omitted for clarity.

Abbreviations: CFU, colony forming unit; cpd, compound; MIC, minimum inhibitory concentration.

presence of sulfur and amidine functions. ${ }^{22}$ Compound 5B showed exceptional activity by inhibiting the bacterial growth at $8 \mu \mathrm{M}$. The only difference between Compound 5B and 3B is the extra thiophene ring contained in the former compound. The possibility that this extra thiophene ring is responsible for this remarkable antibacterial activity cannot be ruled out. In a previous study, compounds containing a thiophene ring were found to be more active than those containing furan or pyrrole rings. ${ }^{20}$ Many sulfur-containing compounds have been reported to have antimicrobial activity against bacteria. ${ }^{23,24}$ Similarities in the inhibition pattern could be noted between each of the following groups of compounds: $1 \mathrm{~A}$ and $2 \mathrm{~A}$;
$1 \mathrm{~B}$ and $2 \mathrm{~B} ; 3 \mathrm{~B}$ and $4 \mathrm{~B}$; and $3 \mathrm{~A}, 4 \mathrm{~A}$, and $5 \mathrm{~A}$. In killing the bacteria, the bichalcophenes behaved like many broadspectrum antibiotics and were equally effective against both Gram-negative and Gram-positive bacteria; their mechanism may be through inhibition of the synthesis of nucleic acids and/or protein. ${ }^{25}$ In a previous study, bichalcophenes were found to cause the degradation of bacterial DNA,,${ }^{14}$ but further studies are required to determine the mechanism(s) of action through which these antibacterial agents may act.

In a dose-dependent manner, all bichalcophenes under investigation, except Compounds 2A, 3A, and 4A, had synergic interactions with tetracycline against almost all strains 
A

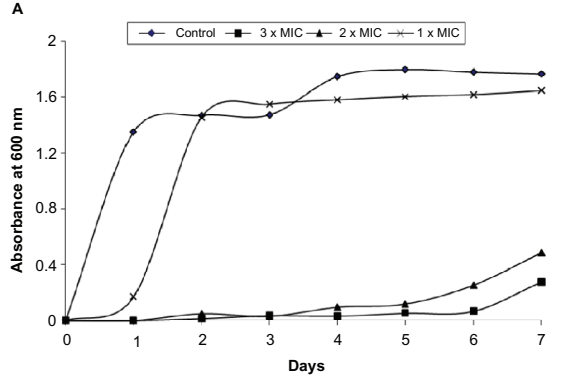

B
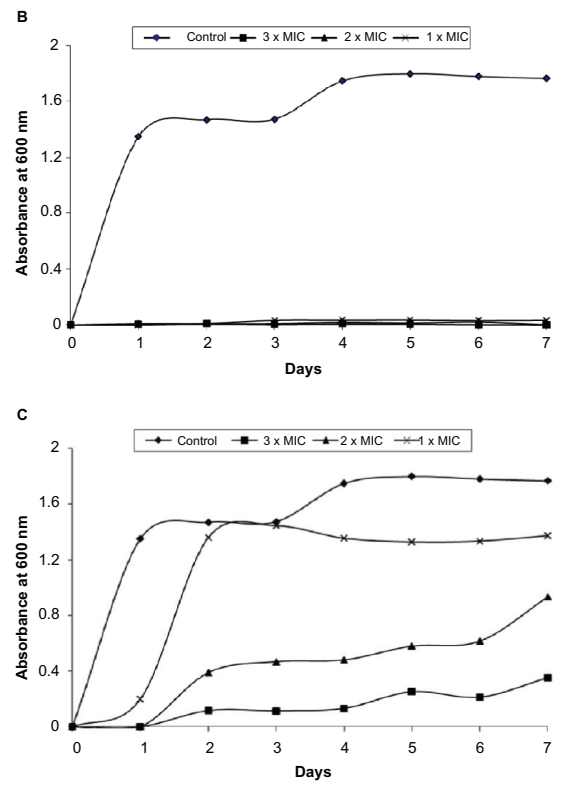

E

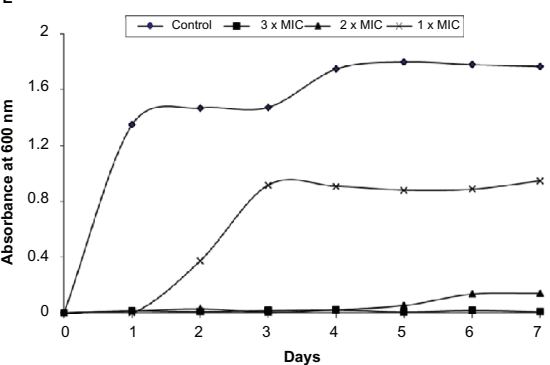

$\mathrm{F}$
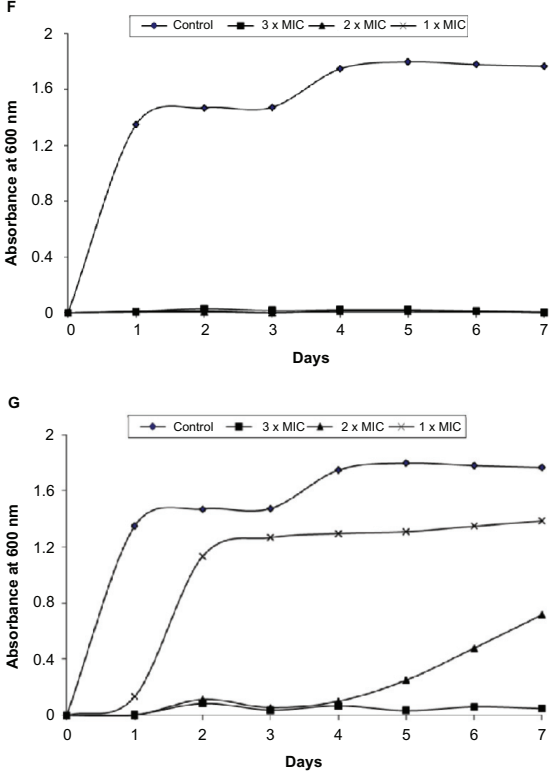

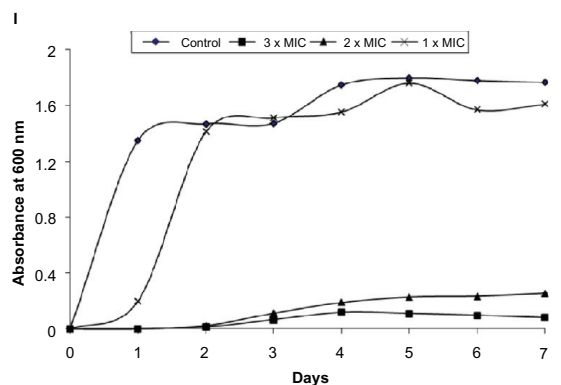

J
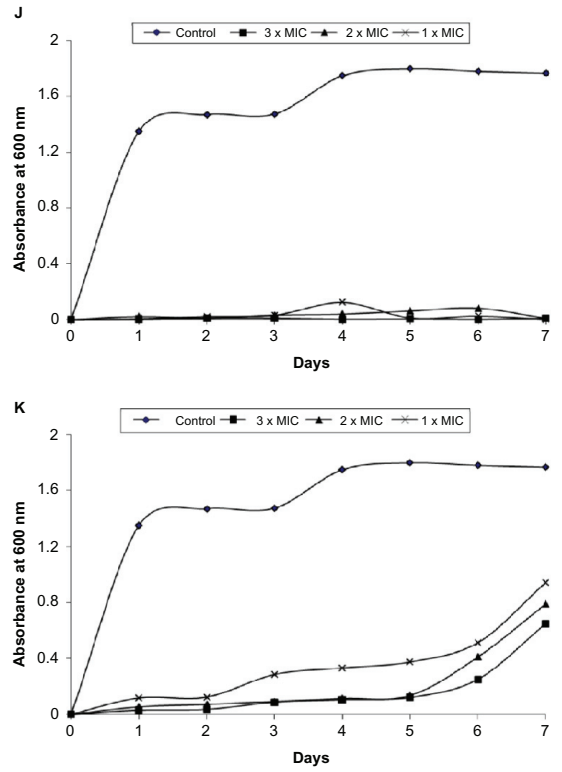
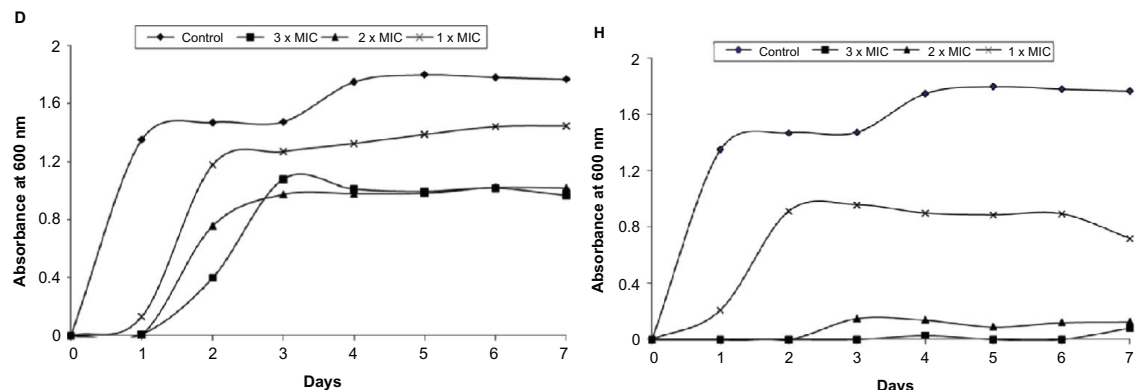

Figure 3 Development of spontaneous resistant variants of Escherichia coli toward bichalcophenes or tetracycline $(3,2$, and I $\times$ MIC) over 7 days. (A) Compound IA; (B) Compound IB; (C) Compound 2A; (D) Compound 2B; (E) Compound 3A; (F) Compound 3B; (G) Compound 4A; (H) Compound 4B; (I) Compound 5A; (J) Compound 5B; (K) tetracycline.

Notes: Data are expressed as the mean of three independent assays. Standard error of the mean has been omitted for clarity.

Abbreviation: MIC, minimum inhibitory concentration.

tested except $S$. aureus (Table 2). Compounds 2B and 5B were the most effective and significantly elevated the tetracycline activity against all organisms, while $2 \mathrm{~A}, 3 \mathrm{~A}$, and $4 \mathrm{~A}$ were the least effective. These compounds are all mononitriles and have at least one furan ring and two of them have pyridyl rings. Compound 2A (mononitrile bifuran with pyridyl ring) antagonized the actions of tetracycline against almost all bacterial strains investigated. Similar to our MIC findings, the monocationic bichalcophenes $(2 \mathrm{~B}, 3 \mathrm{~B}, 4 \mathrm{~B}$, and $5 \mathrm{~B})$ were more effective than the corresponding mononitrile derivatives $(2 \mathrm{~A}$,
$3 \mathrm{~A}, 4 \mathrm{~A}$, and $5 \mathrm{~A}$ ). This differentiation in action was evident in $P$. aeruginosa, where $2 \mathrm{~A}, 3 \mathrm{~A}$, and $4 \mathrm{~A}$ antagonized the inhibitory actions of tetracycline (Table 2). Taken together, the bichalcophenes used in this study can be arranged in descending order according to their ability to potentiate tetracycline activity against bacteria: $2 \mathrm{~B}$ and $5 \mathrm{~B}>>1 \mathrm{~B}, 3 \mathrm{~B}$, and $1 \mathrm{~A}>>4 \mathrm{~B}$ and $5 \mathrm{~A}>>3 \mathrm{~A}>>4 \mathrm{~A}>>2 \mathrm{~A}$. From this, it is clear that the monocationic derivatives were the most effective.

The in vitro pharmacodynamic properties of bichalcophenes were investigated by studying the PAE against $E$. coli. 
Any agent that induces a long antibiotic PAE may secure longer dosing intervals without losing the antibiotic's efficacy. ${ }^{26} \mathrm{E}$. coli exposed to either tetracycline or most bichalcophenes was able to recover and grow 2-3 hours post-exposure. The low value obtained in the present study after exposure to tetracycline has been previously reported. ${ }^{27}$ Two compounds (3B and $5 \mathrm{~B})$ resulted in a remarkable delay in bacterial growth (PAE) of up to 5-6 hours after exposure; not surprisingly, these compounds were monocationic phenyl bichalcophenes. With the exception of 3A, all mononitrile bichalcophene (phenyl or pyridyl) derivatives when combined with tetracycline had no significant effect on the PAE. Combining monocationic phenyl bichalcophenes (1B, 3B, and 5B) with tetracycline resulted in a significant 6-7-hour delay in bacterial growth. The presence of a pyridyl ring in Compounds $2 \mathrm{~B}$ and $4 \mathrm{~B}$ reduced the ability of these monocationic derivatives, resulting in a 4-hour delay in PAE (Figure 2).

In the search for new antibacterial agents, it is not enough to prove their efficacy; it is also necessary to investigate the rate of resistance development toward these new agents. In our study, after only 1 day of incubation, $E$. coli developed resistance to all mononitrile derivatives (1A-5A), monocationic pyridyl bichalcophenes ( $2 \mathrm{~B}$ and $4 \mathrm{~B}$ ), and tetracycline at the low concentration of $1 \times$ MIC. Similar findings have previously been reported for tetracycline. ${ }^{28}$ At the highest concentration of $3 \times \mathrm{MIC}$, the bacteria were not able to develop resistance against almost all bichalcophenes after 7 days of incubation, but overcame tetracycline and started to grow after 5 days. In contrast, the bacteria failed to develop resistance toward the monocationic phenyl bichalcophenes (1B, 3B, and 5B), even after 7 days, at all concentrations investigated (Figure 3).

In conclusion, in our study, a structural activity relationship was evident, as the presence of mononitrile or pyridyl groups and, to a lesser extent, the furan ring, reduced antibacterial activity, while the presence of a phenyl, monocationic, or thiophene ring clearly enhanced antibacterial activity. Recently, the National Cancer Institute Developmental Therapeutics Program examined these bichalcophenes for anticancer activity in 58 cell lines and found that monocationic bichalcophenes were more active than the corresponding aza-analogs and that $1 \mathrm{~B}, 4 \mathrm{~B}$, and $5 \mathrm{~B}$ were the most active compounds (unpublished data). These bichalcophenes not only have antibacterial properties but can also potentiate the activity of antibiotics currently in use. As it is unlikely that bacteria could develop resistance to these novel compounds, their possible clinical effectiveness is suggested. Two of these bichalcophenes (1A and $1 \mathrm{~B}$ ) have been tested in mice and found to be not toxic. ${ }^{29}$ Treatment of methicillin-resistant Staphylococcus aureus-infected mice with these bichalcophenes resulted in significant reductions in the viable bacterial count in blood, liver, kidney, and spleen. The structural activity relationship in the present study was also confirmed in vivo, as Compound $1 \mathrm{~B}$ was superior to $1 \mathrm{~A}$ and sometimes both provided better antistaphylococcal agents than vancomycin against methicillinresistant $S$. aureus pathogenesis. ${ }^{29}$

\section{Acknowledgment}

This project was supported by the Deanship of Scientific Research at King Faisal University (grant no 130143).

\section{Disclosure}

The authors declare no conflicts of interest in this work.

\section{References}

1. Trémolières F. When the antibiotic miracle turns into a nightmare. Med Sci (Paris). 2010;26:925-929. French.

2. Kennedy B, O’Connor B, Korn B, Gibbons N, O’Connor T, Keane J. Multi-drug resistant tuberculosis: experiences of two tertiary referral centres. Ir Med J. 2011;104(6):182-185.

3. Kutty N. Treating children without antibiotics in primary healthcare. Oman Med J. 2011;26(5):303-305.

4. Checchi F, Barrett MP. African sleeping sickness. BMJ. 2008; 336(7646):679-680.

5. Soeiro MN, de Castro SL, de Souza EM, Batista DG, Silva CF, Boykin DW. Diamidine activity against trypanosomes: the state of the art. Curr Mol Pharmacol. 2008;1(2):151-161.

6. Libman MD, Miller MA, Richards GK. Antistaphylococcal activity of pentamidine. Antimicrob Agents Chemother. 1990;34(9):1795-1796.

7. Werbovetz K. Diamidines as antitrypanosomal, antileishmanial and antimalarial agents. Curr Opin Investig Drugs. 2006;7(2):147-157.

8. Taylor R. Thiophene and its derivatives. In: Gronowitz S, editor. The Chemistry of Heterocyclic Compounds. Hoboken, NJ: Wiley; 1985: 261-323.

9. Soeiro MN, De Souza EM, Stephens CE, Boykin DW. Aromatic diamidines as antiparasitic agents. Expert Opin Invest Drugs. 2005;14(8):957-972.

10. Wilson WD, Nguyen B, Tanious FA, et al. Dications that target the DNA minor groove: compound design and preparation, DNA interactions, cellular distribution and biological activity. Curr Med Chem Anticancer Agents. 2005;5(4):389-408.

11. Wenzler T, Boykin DW, Ismail MA, Hall JE, Tidwell RR, Brun R. New treatment option for second-stage African sleeping sickness: in vitro and in vivo efficacy of aza analogs of DB289. Antimicrob Agents Chemother. 2009;53(10):4185-4192.

12. Del Poeta M, Schell WA, Dykstra CC, et al. In vitro antifungal activities of a series of dication-substituted carbazoles, furans, and benzimidazoles. Antimicrob Agents Chemother. 1998;42(10): 2503-2510.

13. Ismail MA, El Bialy SA, Brun R, et al. Dicationic phenyl-2,2'-bichalcophenes and analogues as antiprotozoal agents. Bioorg Med Chem. 2011;19(2):978-984.

14. Youssef MM, Al-Omair MA, Ismail MA. Synthesis, DNA affinity, and antimicrobial activity of 4-substituted phenyl-2,2'-bichalcophenes and aza-analogues. Med Chem Res. 2012;21:4074-4082.

15. Spangler SK, Lin G, Jacobs MR, Appelbaum PC. Postantibiotic effect and postantibiotic sub-MIC effect of levofloxacin compared to those of ofloxacin, ciprofloxacin, erythromycin, azithromycin, and clarithromycin against 20 pneumococci. Antimicrob Agents Chemother. 1998;42(5):1253-1255. 
16. National Committee for Clinical Laboratory Standards (NCCLS). Performance Standards for Antimicrobial Susceptibility Testing: Eleventh Informational Supplement. M100-S11. Wayne, PA: NCCLS; 2001.

17. Mackay ML, Milne K, Gould IM. Comparison of methods for assessing synergic antibiotic interactions. Int J Antimicrob Agents. 2000;15(2):125-129.

18. Craig WA, Gudmundsson S. Postantibiotic effect. In: Lorian V, editor. Antibiotics in Laboratory Medicine. Philadelphia, PA: Lippincott Williams \& Wilkins; 1996:296-329.

19. Pillai SP, Pillai CA, Shankel DM, Mitscher LA. The ability of certain antimutagenic agents to prevent development of antibiotic resistance. Mutat Res. 2001;496(1-2):61-73.

20. Boschi D, Guglielmo S, Aiello S, Morace G, Borghi E, Fruttero R. Synthesis and in vitro antimicrobial activities of new (cyano-NNO-azoxy) pyrazole derivatives. Bioorg Med Chem Lett. 2011;21(11):3431-3434.

21. Xiao ZP, He XB, Peng ZY, et al. Synthesis, structure, molecular docking, and structure-activity relationship analysis of enamines: 3-aryl4-alkylaminofuran-2(5H)-ones as potential antibacterials. Bioorg Med Chem. 2011;19(5):1571-1579.

22. Thebault P, Taffin de Givenchy E, Levy R, Vandenberghe Y, Guittard F, Géribaldi S. Preparation and antimicrobial behaviour of quaternary ammonium thiol derivatives able to be grafted on metal surfaces. Eur J Med Chem. 2009;44(2):717-724.

23. Kim S, Kubec R, Musah RA. Antibacterial and antifungal activity of sulfurcontaining compounds from Petiveria alliacea L. J Ethnopharmacol. 2006;104(1-2):188-192.
24. Dekié BR, Radulović NS, Dekić VS, Vukićević RD, Palić RM. Synthesis and antimicrobial activity of new 4-heteroarylamino coumarin derivatives containing nitrogen and sulfur as heteroatoms. Molecules. 2010;15(4):2246-2256.

25. Wood K, Nishida S, Sontag ED, Cluzel P. Mechanism-independent method for predicting response to multidrug combinations in bacteria. Proc Natl Acad Sci U S A. 2012;109(30):12254-12259.

26. Güzel $\mathrm{CB}$, Gerçeker AA. In vitro activities of various antibiotics, alone and in combination with colistin methanesulfonate, against Pseudomonas aeruginosa strains isolated from cystic fibrosis patients. Chemotherapy. 2008;54(2):147-151.

27. Athamna A, Athamna M, Medlej B, Bast DJ, Rubinstein E. In vitro post-antibiotic effect of fluoroquinolones, macrolides, beta-lactams, tetracyclines, vancomycin, clindamycin, linezolid, chloramphenicol, quinupristin/dalfopristin and rifampicin on Bacillus anthracis. J Antimicrob Chemother. 2004;53(4):609-615.

28. Yang $\mathrm{H}$, Chen $\mathrm{S}$, White DG, et al. Characterization of multiple-antimicrobial-resistant Escherichia coli isolates from diseased chickens and swine in China. J Clin Microbiol. 2004;42(8):3483-3489.

29. El-Sayed WM, Hussin WA, Ismail MA. Efficacy of two novel 2,2'-bifurans to inhibit methicillin-resistant Staphylococcus aureus infection in male mice in comparison to vancomycin. Drug Des Devel Ther. 2012;6:279-287.
Drug Design, Development and Therapy

\section{Publish your work in this journal}

Drug Design, Development and Therapy is an international, peerreviewed open-access journal that spans the spectrum of drug design and development through to clinical applications. Clinical outcomes, patient safety, and programs for the development and effective, safe, and sustained use of medicines are a feature of the journal, which

\section{Dovepress}

has also been accepted for indexing on PubMed Central. The manuscript management system is completely online and includes a very quick and fair peer-review system, which is all easy to use. Visit http://www.dovepress.com/testimonials.php to read real quotes from published authors.

Submit your manuscript here: http://www.dovepress.com/drug-design-development-and-therapy-journal 